\title{
DYSKUSJE WOKÓŁ METODOLOGICZNEGO STATUSU TEORII POZNANIA W FILOZOFII PODMIOTU
}

\begin{abstract}
W artykule bada się zagadnienie statusu metodologicznego teorii poznania. Na przestrzeni wieków status ten ulegał ciągłej modyfikacji w kierunku przyznawania teorii poznania w filozofii coraz większego znaczenia aż do wysunięcia jej na pierwsze miejsce wśród dyscyplin filozoficznych. Stosując metodę analizy historycznej, zwanej w filozofii klasycznej metodą historyzmu, autor wskazuje na trudności związane z traktowaniem teorii poznania jako filozofii pierwszej. Wychodząc od analizy powiązań problematyki teoriopoznawczej z dyscyplinami filozofii klasycznej, pokazuje drogę rozwoju filozoficznej refleksji, na której doszło do wysunięcia teorii poznania na pierwsze miejsce wśród dyscyplin filozoficznych oraz negatywne konsekwencje takiego statusu teorii poznania dla uprawiania filozofii. Najważniejszą z nich jest zerwanie związku filozofii z realnie istniejącą rzeczywistością i zamknięcie filozoficznego poznania w polu ludzkiej świadomości. W gruncie rzeczy poznanie zostało zastapione refleksją nad własnymi aktami poznawczymi. W ten sposób filozofia pozbawiła poznający (myślący) podmiot możliwości kontroli swoich procesów poznawczych poprzez odwoływanie się do realnego bytu. Według tomistów egzystencjalnych sposobem na poradzenie sobie ze wspomnianymi trudnościami jest wypracowanie innego niż w filozofii podmiotu statusu metodologicznego teorii poznania. Otóż teoria poznania powinna być dyscypliną, która źródłowo opisuje poznanie i czyni z niego przedmiot filozoficznego wyjaśnienia. Wtedy jednak teoria poznania nie może być filozofią pierwszą jej punktem wyjścia nie może być wówczas analiza świadomości. Teoria poznania, badając poznanie, jest wtedy dyscypliną przedmiotową strukturalnie powiązaną z metafizyką.

Slowa kluczowe: filozofia podmiotu, filozofia klasyczna, filozofia pierwsza, teoria poznania, metafizyka, tomizm egzystencjalny.
\end{abstract}

\section{WPROWADZENIE}

Od pewnego czasu dominuje w filozofii pogląd, że teoria poznania jest pierwszą wśród dyscyplin filozoficznych. Niektórzy posuwają się jeszcze dalej, utrzymując, że teoria poznania jest synonimem filozofii. A wtedy wszystkie problemy filozoficzne są problemami teoriopoznawczymi. Wyróżnioną pozycję teoria poznania zdobyła w nowożytności za sprawą przedstawicieli filozofii podmiotu ${ }^{2}$. Czy jednak takie miejsce teorii poznania wśród dyscyplin filozoficznych jest słuszne? Odpowiedzią na to pytanie będzie rekonstrukcja głównych historyczno-filozoficznych rozwiązań dotyczących metodologicznego statusu teorii poznania. Chociaż metodologiczny status teorii poznania jest określony przez jej przedmiot, metodę $\mathrm{i}$ cel, to głównie ze względu na naturę

\footnotetext{
${ }^{1}$ Ks. dr Andrzej Sołtys, Zakład Nauk Humanistycznych, Wydział Zarządzania, Politechnika Rzeszowska, ul. Poznańska 1, 35-084 Rzeszów, tel. 017 8651204, e-mail: asoltys@prz.edu.pl, ${ }^{2}$ Zob. R. Descartes, Medytacje o filozofii pierwszej, przeł. J. Hartman, Zielona Sowa, Kraków 2006.
} 
przedmiotu wykształciły się przedmiotowa i metaprzedmiotowa koncepcja teorii poznania ${ }^{3}$. Dzieje filozofii obrazują, jak wspomniane koncepcje teorii poznania dojrzewają i z sobą konkurują.

\section{PROBLEMATYKA TEORIOPOZNAWCZA W FILOZOFII KLASYCZNEJ}

Metodologiczny status koncepcji teorii poznania wykształcał się w relacji do metafizyki. W filozofii klasycznej to metafizyka uchodziła za dyscyplinę pierwszą ${ }^{4}$. Arystoteles traktuje ją jako najwyższy i najogólniejszy ${ }^{5}$ typ poznania filozoficznego dotyczący substancjalnych form rzeczywistości. Na gruncie tej dyscypliny wyjaśniano wszelki byt we wskazanym aspekcie poprzez dociekanie ostatecznych jego przyczyn. Z racji przedmiotu, aspektu patrzenia na ten przedmiot oraz celu wyjaśniania metafizyka dostarczała innym dyscyplinom swego uzasadnienia, w tym także uzasadnienia teoriopoznawczej problematyki ${ }^{6}$. Oczywiście nie twierdzimy, że Arystoteles wyróżniał teorię poznania jako odrębną dyscyplinę filozoficzną ${ }^{7}$, ale jedynie to, że gdyby była przez niego wydzielona, to musiałaby być dyscypliną zależną $\mathrm{w}$ stosunku do metafizyki, podobnie jak wyróżniana przez niego filozofia praktyczna czy logika.

Niektórzy, próbując znaleźć miejsce dla teorii poznania w filozoficznym systemie Arystotelesa, nie tyle wskazują na zależność zagadnień teoriopoznawczych od filozofii pierwszej, co przeciwstawiają sobie te dyscypliny. Skoro metafizyka zajmuje się bytem, a logika, mając w stosunku do filozofii charakter instrumentalny, prowadzi dociekania nad ludzką wiedzą, to we wskazanym przydziale zadań zaznacza się umiarkowany dualizm bytu i poznania $^{8}$. Na tej podstawie można by utrzymywać, że Arystoteles daje podstawę do podziału filozofii na metafizykę traktującą o bycie, logikę badającą ludzką wiedzę, czyli rezultaty poznania, natomiast teoria poznania badałaby poznanie jako czynność. W

\footnotetext{
${ }^{3}$ Niektórzy wskazują także na trzecią koncepcję teorii poznania rozwijaną przez dwudziestowieczne nurty filozofii pozytywistycznej. Teoria poznania w ich ujęciu sprowadza się ostatecznie do logicznych analiz dotyczących języka. Por. L. Wciórka, Teoria poznania, Papieski Wydział Teologiczny Redakcja Wydawnictw, Poznań 1996, s. 11. Przykładem takiej teorii poznania jest podręcznik epistemologii Jana Woleńskiego. Zob. J. Woleński, Epistemologia, Wydawnictwo Naukowe PWN, Warszawa 2005.

${ }^{4}$ Arystoteles nie posługuje się nazwą „metafizyka”, lecz „filozofia pierwsza”. Generalnie znawcy Arystotelesa właśnie w jego filozofii pierwszej dostrzegają problematykę, która później została nazwana metafizyką. Ale są też opinie odmienne, a mianowicie, że Arystotelesa „filozofia pierwsza" dotyczy po prostu bytu pierwszego - Absolutu, natomiast filozofia druga czy wtórna zajmuje się wyłącznie bytami przygodnymi. Zob. J. Kalinowski, O istocie i jedności filozofii, „Roczniki Filozoficzne” 6/1 (1958), s. 5-17.

${ }_{6}^{5}$ Metafizyka w pismach Arystotelesa jest nauką operującą trzecim stopniem abstrakcji.

${ }^{6}$ Obszernie na temat stosunku innych dyscyplin filozoficznych do tak zwanej filozofii pierwszej, czyli metafizyki w filozofii Arystotelesa, zob. A. Mansion, Philosophie première, philosophie seconde et métaphysique chez Aristote, „Revue Philosophique de Louvain” 1958/56, s. 165-221.

${ }^{7}$ Autorem, który pierwszy użył nazwy epistemologia w odniesieniu do tak zwanej filozofii pierwszej jest E. Reinhold, Theorie des Menslichen Erkenntnisvermögens und Metaphysik, I-II, Gotha $1832-1835$.

${ }^{8}$ Por. S. Kamiński, Teoria bytu a inne dyscypliny filozoficzne, „Roczniki Filozoficzne” 25/1 (1975), s. 6 .
} 
następnych wiekach nie podjęto próby metodologicznej determinacji dyscypliny filozoficznej badającej zagadnienia związane z poznaniem.

Podjęto się tego zadania dopiero w szczytowym okresie rozwoju średniowiecza. Wtedy święty Tomasz z Akwinu rozwiną poczynione przez Arystotelesa metodologiczne ustalenia. Nawiązując do Arystotelesa, traktował on metafizykę jako filozofię pierwszą, chociaż zmodyfikował jej metodę przedmiot i cel. Gdy Arystoteles dochodził do pojęcia bytu na drodze abstrakcji, tak święty Tomasz konstruował pojęcie bytu na drodze separacji metafizycznej. Gdy dla tego pierwszego przedmiotem były choć substancjalne, to jednak abstrakcyjne formy rzeczywistości (substancja jako natura), tak dla świętego Tomasza był nim realnie istniejący bytowy konkret (istota konkretnie istniejąca). Wreszcie gdy dla Arystotelesa celem metafizycznego poznania była głównie wiedza definicyjna, to znaczy wiedza dotycząca przyczyny formalnej, tak święty Tomasz cel ten związał z przyczynowością zasadzającą się na podstawowym złożeniu realnego bytu z istoty $\mathrm{i}$ istnienia. Akwinata, traktując filozofię bytu jako najważniejszą wśród dyscyplin filozoficznych, implicite wskazał na przedmiot metafizyki jako totum divisionis filozofii. Przedmiot metafizyki zakresowo ogarniał wszelki byt. Natomiast poszczególne dyscypliny filozofii wydzielono na podstawie partykularyzacji tegoż bytu. $\mathrm{Z}$ racji najszerszego zakresu pojęcia przedmiotu metafizyki święty Tomasz określał ten przedmiot jako ens commune. ${ }^{9}$. Filozoficzny system świętego Tomasza uzyskał tym samym metodologiczną przejrzystość. W świetle przedstawionych zasad uporządkowania dyscyplin filozofii trzeba dopiero szukać miejsca dla teorii poznania we wskazanym systemie filozoficznym.

Święty Tomasz z Akwinu nie napisał żadnego traktatu z zakresu teorii poznania. Nie znaczy to jednak, że nie interesował się zagadnieniami teoriopoznawczymi. Otóż zajmował się nimi w kontekście badanej problematyki metafizycznej, co stanowi dodatkową rację przemawiającą za tym, że teorię poznania należy postrzegać $\mathrm{w}$ jego filozofii jako jedną z metafizyk szczegółowych. I chociaż nie wskazał on przedmiotu dla tej gałęzi wiedzy, to jednak w świetle przyjętej zasady porządkowania dyscyplin filozoficznych teoria poznania powinna mieć charakter dyscypliny przedmiotowej. Dowodzi tego badanie przez świętego Tomasza kwestii procesów poznawczych na gruncie metafizyki. Wykluczenie z metafizyki zagadnień dotyczących poznania byłoby równoznaczne $\mathrm{z}$ nadaniem teorii poznania statusu pomocniczej nauki $\mathrm{w}$ filozofii. Zaprezentowana interpretacja metodologicznego usytuowania problematyki teoriopoznawczej w systemie filozofii świętego Tomasza nie jest jedyna.

Niektórzy sądzą, że fillozofia świętego Tomasza upoważnia, aby podstawą podziału filozofii uczynić nie przedmiot, lecz metodę poznania filozoficznego ${ }^{10}$. Nie wydaje się jednak, aby wydzielenie dyscyplin filozofii ze względu na metodę było alternatywą podziału filozofii na podstawie zasady partykularyzacji przedmiotu metafizyki. Raczej jest on podziałem wyższego stopnia w podziale filozofii ze względu na przedmiot. Jeśli przedmiotem filozofii jest realnie istniejący byt, a poszczególne dyscypliny filozofii są wydzielane na podstawie zasady partykularyzacji tego bytu, to można już wydzielone dyscypliny podzielić na te, które w rozważaniach przedmiotowych odwołują się do modus

\footnotetext{
9 „Philosophum primum, qui considerat ens commune et ea quae sunt separata a motu”. Św. Tomasz z Akwinu, Summa contra gentiles, II, 37.

${ }^{10}$ Por. S. Kamiński, Dziedziny teorii bytu, [w:] Studia z filozofii Boga, red. B. Bejze, t. 3, Warszawa 1977, s. 80.
} 
rationalis, oraz te, które stosują modus intellectualis. W efekcie skrzyżowania tych dwóch podziałów dochodzi do jeszcze ostrzejszego wyróżnienia dyscyplin filozoficznych (metafizycznych). Jedne należałyby do grupy tych dyscyplin, które tworzą teorię bytu danego bezpośrednio (materialnego) i w nich obowiązywałaby metoda modus rationalis, dopiero w oparciu na teorii takiego bytu można by było dochodzić do nauki zajmującej się najogólniejszymi zasadami bytu, w której modus intellectualis byłby jej metodą. W sensie ścisłym metafizyką można by nazwać dyscyplinę, której przedmiotem jest ens commune, modus intellectualis zaś - jej metodą. Przy takim ostrym oddzieleniu dyscyplin filozofii związanych z jedną bądź drugą metodą nie bardzo wiadomo, w której grupie dyscyplin filozoficznych zmieścić zagadnienia dotyczące ludzkiego poznania. Najbardziej nadają się one do badania przez wydzieloną, odrębną od metafizyki dyscyplinę o charakterze metaprzedmiotowym.

\section{METODOLOGICZNY STATUS TEORII POZNANIA W FILOZOFII} PODMIOTU

Za autora i twórcę metaprzedmiotowej koncepcji teorii poznania uchodzi Kartezjusz. Zdawał on sobie sprawę $\mathrm{z}$ zamętu, jaki panował w filozofii europejskiej. W odnowionej i zrewolucjonizowanej filozofii Kartezjusz upatrywał sposób na zintegrowanie nękanej wojnami Europy. Nowa filozofia nie mogła się już odwoływać do świadectwa zmysłów, zmysły bowiem ze swej istoty zawodzą, na co wskazują przeciwstawne filozoficzne prądy myślowe opierające swoje przekonania właśnie na świadectwie zmysłów. Zmysły nie dostarczają kryteriów, na których podstawie można by odróżnić jawę od snu.

Kartezjusz, kształcąc się w jezuickim kolegium La Flèche, zaznajomił się z filozofia Franciszka Suáreza, wpływowego hiszpańskiego jezuity. Dla Suáreza natomiast sprawą podstawową w konstruowaniu systemu było określenie przedmiotu filozofii. Według niego przedmiot filozofii był pojęty esencjalistycznie (ens ut nomen). Otóż bytem jest istota i dlatego wystarczy studium istoty, aby uzyskać adekwatną wiedzę o bycie. Poznawczo ujęta istota jest z kolei pojęciem bytu. Przy czym Suárez odróżnił pojęcie subiektywne (formalne) i obiektywne ${ }^{11}$. Nawiązując do myśli Awicenny o naturze trzeciej, istotę zrozumiał jako pojęcie obiektywne. Inaczej mówiąc, był nim byt ujęty w swych strukturach koniecznościowych. Natomiast pojęciem subiektywnym był obraz znak, poprzez który widzi się pojęcie obiektywne. Pojęciem obiektywnym było to, co poznajemy, pojęciem subiektywnym zaś to, w jaki sposób poznajemy. Poprzez pojęcie subiektywne widzimy samą rzecz daną w pojęciu obiektywnym.

Kartezjusz zakwestionował sens pojęcia obiektywnego. Uznał, że mówienie o pojęciu obiektywnym jest niepotrzebnym ,podwajaniem rzeczywistości”. Pojęcie dotychczas uznawane za obiektywne nazwał idea (subiektywna) i uznał ją za jedyny przedmiot poznania $^{12}$. Sprowadził w ten sposób pojęcie obiektywne do pojęcia subiektywnego. Był przekonany, że złudnemu świadectwu zmysłów odpowiada właśnie suarezjańskie pojęcie obiektywne. A dopiero poznając ideę, poznajemy samą rzecz, idea bowiem jest tej rzeczy obrazem. Idea jasna i wyraźna to przedmiot pożądanego wartościowego poznania. Kartezjusz wyznaczył filozofii badanie poznania oraz wiedzy prawdziwej. Zagadnienie

\footnotetext{
${ }^{11}$ Por. F. Suárez, Disputationes metaphysicae, Bd. 2, Hildesheim 1998, disp. II, sect. 1, 1.

${ }^{12}$ Por. M. A. Krapiec, Epistemologia, [w:] Powszechna encyklopedia filozofii, red. A. Maryniarczyk i in., t. 3, Polskie Towarzystwo Tomasza z Akwinu, Lublin 2002, s. 196.
} 
tego, co się poznaje, zeszło na dalszy plan. Krytyka poznania, a więc tego, w jaki sposób poznajemy, uprzedziła wyjaśnianie tego, że poznajemy i co poznajemy. Kartezjańskie ,jak poznajemy” zastapiło „co poznajemy”. Odtąd miejsce metafizyki jako filozofii pierwszej zajęły zagadnienia związane z krytyką poznania. Teoria poznania dokonująca wspomnianej krytyki uzyskała odmienny niż w nurcie filozofii klasycznej metodologiczny status. W niej punktem wyjścia było radykalne metodyczne wątpienie w to, że coś w ogóle wiem, z pokonania sceptycyzmu zaś uczyniono podstawowe zadanie filozofii. W gruncie rzeczy to rozważania o metodzie stały się punktem wyjścia filozofii ${ }^{13}$.

W filozofii nastąpił zwrot ku badaniu świadomości ludzkiej. Wysunięcie teorii poznania na pierwsze miejsce wśród dyscyplin filozoficznych spowodowało, że metafizyka (o ile istniała jeszcze jakakolwiek racja jej uprawiania) mogła być już tylko nabudowana na wątpiącym podmiocie, a wtedy jej przedmiotem nie mogło być nic innego poza ideami. Życie poznawcze zostało w tym kontekście pojęte jako uświadamianie sobie tego, co jest stale obecne w strumieniu naszej świadomości, lecz w sposób niewyraźny. W konsekwencji nastapiło oderwanie ludzkiego poznania od rzeczywistości i zamknięcie poznania $\mathrm{w}$ polu świadomości i „pułapce refleksji”, ${ }^{4}$. Wykształcił się typ filozofii reprezentacjonalistycznej, w której poznanie spontaniczne danego przedmiotu zastąpiono refleksją nad własnymi aktami poznawczymi. Filozofia, czyniąc swoim przedmiotem własne reprezentacje poznawcze, pozbawiła poznający (myślący) podmiot możliwości kontroli swoich procesów poznawczych poprzez odwołanie się do realnego bytu i tym samym skazała go na immanencję własnej świadomości. Opisany zwrot podmiotu ku samemu sobie nie był spowodowany naturalnym porządkiem poznania, lecz był on następstwem kartezjańskiego woluntaryzmu najbardziej widocznego w jego koncepcji sądu ${ }^{15}$.

Zarysowany nurt filozoficznego myślenia rozwinął Immanuel Kant. Również dla niego ukrytycznienie poznania było głównym zadaniem filozofii. Analogicznie do filozofii Kartezjusza poznawanie przedmiotu znalazło się w ogniu jego krytyki, nie natomiast to, co poznajemy. Kant chociaż nie negował istnienia rzeczywistości, to jednak w krytyce poznania upatrywał jedyną rację jej rozumienia. Dla filozofa z Królewca nie metafizyka, ale metaprzedmiotowo pojęta teoria poznania była więc filozofią pierwszą. W niej naukotwórcze pytanie „dlaczego" zostało definitywnie wyparte przez pytanie o warunki wiedzy prawdziwej „,o mogę wiedzieć”"

Z potrzeby wiedzy prawdziwej wykształcił się mentalistyczny paradygmat uprawiania filozofii ${ }^{17}$. Zgodnie $\mathrm{z}$ nim filozofia bada udział świadomości $\mathrm{w}$ konstytuowaniu rzeczywistości. Rozumny podmiot występuje jako czynnik aktywny, wnosi do poznania pewne schematy służące uporządkowaniu danych spostrzeżeniowych $i$ to $z$ tej racji ma on powszechną ważność. Całościowe badanie subiektywnych warunków poznania Kant

\footnotetext{
${ }^{13}$ Zob. R. Descartes, Rozprawa o metodzie, przeł. T. Żeleński-Boy, Wydawnictwo Marek Derewecki, Kęty 2009.

${ }^{14}$ Zob. W. Chudy, Rozwój filozofowania a „pułapka refleksji”, Redakcja Wydawnictw KUL, Lublin 1995, s. 115-171.

${ }^{15}$ Por. B. Paź, Naczelna zasada racjonalizmu, „Aureus”, Kraków 2007, s. 57.

${ }^{16}$ Por. I. Kant, Krytyka czystego rozumu, przeł. R. Ingarden, t. 2, PWN, Warszawa 1986, B 833.

${ }^{17}$ Obszernie na temat paradygmatów uprawiania filozofii zob. Filozofia, podstawowe pytania, red. E. Martens i H. Schnadelbach, przeł. K. Krzemieniowa, Wiedza Powszechna, Warszawa 1995, s. 66-97.
} 
nazwał „filozofią transcendentalną”. „Transcendentalnym nazywam wszelkie poznanie, które zajmuje się w ogóle nie tyle przedmiotami, ile naszym sposobem poznawania przedmiotów, o ile ten ma być a priori możliwy" ". Kant w swej teorii poznania nie wyjaśniał faktyczności poznania, lecz tylko jego strukturę. Nie chodziło mu również o przebadanie struktury poznania w ogóle, lecz tylko takiego typu poznania, w którym dochodzi się do wiedzy powszechnie ważnej, czyli nauki. Metodę uczynił punktem wyjścia filozofii. Odrzucił dotychczas przyjmowaną zasadę, że metoda poznania musi odpowiadać przedmiotowi poznania. Metoda w przekonaniu Kanta współkonstytuuje przedmiot poznania. Chcąc uwolnić filozofię podmiotu od kartezjańskiego idealizmu epistemologicznego, zmierzał do ponownego związania poznania filozoficznego z takim przedmiotem, który istnieje niezależnie od podmiotu poznającego. Jednakże zmienił rozumienie tego przedmiotu. Uznał, że rzeczywistym przedmiotem dla krytycznego poznania mogą być tylko te dane, które są przekazywane myśli przez wrażenia. Ostatecznie przedmiot poznania jest rezultatem swoistej syntezy między przedmiotowymi zjawiskami i apriorycznymi kategoriami podmiotu, poprzez które podmiot nadaje przedmiotowi sens ${ }^{19}$.

W Kanta krytycznej teorii poznania doszło do pomieszania faktu poznania $\mathrm{z}$ niezależną od poznania rzeczywistością. Konsekwencją tego jest to, że w poznaniu nie można odróżnić treści subiektywnej od treści realnego bytu. Poznanie zostało zredukowane do myślenia. Odtąd analiza bytu intencjonalnego stała się sytuacją macierzystą wszelkiej filozofiii ${ }^{20}$. Filozofowanie zamknięto w ,„pułapce refleksji”, z której nie sposób już utorować drogę do poznania realnie istniejącej rzeczywistości. Niewykonalność tego zadania jeszcze bardziej pogłębił przyjęty przez Kanta agnostycyzm w odniesieniu do rzeczy samych w sobie. Kant, nadając teorii poznania rangę filozofii pierwszej zajmującej się ukrytycznianiem poznania, nie wyjaśnił faktu poznania. Paradoksalnie teorię poznania zepchnął do poziomu nauk pomocniczych filozofii o charakterze metaprzedmiotowym, to znaczy takich nauk, które nie badają przedmiotów realnego świata. Teoria poznania stała się przez to dyscypliną pokrewną logice, metodologii nauk czy teorii nauki, których rolą jest eksplikowanie myśli. Dziedzictwo filozoficznej myśli Kanta zaciążyło nad filozofią europejską XIX i pierwszej połowy XX wieku. Wspomniany wpływ był szczególnie widoczny w nurcie fenomenologii ${ }^{21}$.

W niej teoria poznania nadal zachowała status dyscypliny metaprzedmiotowej. Również Edmund Husserl, uważany za ostatniego filozofa świadomości, traktował teorię poznania jako pierwszą dyscyplinę filozoficzna, której naczelnym zadaniem było ukrytycznienie poznania-myślenia. W świetle fenomenologii Husserla myślenie (cogito) miało jednocześnie charakter immanentny i transcendentny. Poznawana treść jest bytem

\footnotetext{
${ }^{18}$ I. Kant, Krytyka czystego rozumu, przeł. R. Ingarden, t. 1, PWN, Warszawa 1986, B 25. Pojęcie transcendentalizmu ewoluowało. Na temat współczesnego pojmowania transcendentalizmu w filozofii zob. M. Szulakiewicz, Transcendentalizm Kanta a myśl wspótczesna, [w:] Immanuel Kant i świat współczesny, red. K. Śnieżyński, Uniwersytet im. Adama Mickiewicza, Poznań 2004, s. 4965 .

${ }^{19}$ Kantowska tablica kategorii, zob. I. Kant, Krytyka czystego rozumu, B 106.

${ }^{20}$ Por. M.A. Krapiec, O filozofii, Polskie Towarzystwo Tomasza z Akwinu, Lublin 2008, s. 69.

${ }^{21}$ Fenomenologia jest filozofią świadomości, której celem jest dotarcie do transcendentalnych podstaw konstytucji czystej świadomości. Zob. A.B. Stępień, Wstęp do filozofii, Towarzystwo Naukowe KUL, Lublin 2007, s. 266-269.
} 
intencjonalnym. Husserl uznał, że w bycie intencjonalnym (immanentnym) jest odniesienie do świata ${ }^{22}$, ponieważ byt intencjonalny został utworzony z poznawczego ujęcia istniejącego świata. Ale czy intencjonalność pociaga realność? Przecież myśl nie daje podstawy do afirmowania istnienia realnego świata. Mimo wysuniętego fenomenologicznego programu powrotu do rzeczy samej w sobie (Zurück zu den Sachen selbst) Husserl nie związał poznania (myślenia) z realnym światem. A pozostający w nurcie fenomenologii Roman Ingarden, badając różne drogi, na których usiłuje się rozwiązywać ten problem, wykazywał, że są one jałowe poznawczo ${ }^{23}$.

Krytykę poznania jako punkt wyjścia filozofii przyjmowali także niektórzy filozofowie tomistyczni ${ }^{24}$. Wprawdzie przełomowa dla odnowionej filozofii w kręgach filozofów chrześcijańskich była encyklika Leona XIII Aeterini Patris, gdyż skłoniła ich do uprawiania filozofii tomistycznej, to jednak w niektórych odmianach tomizmu ciagle asymilowano elementy filozofii Kanta ${ }^{25}$. Przykładem może być filozofia Désiré Merciera, który podobnie jak Kant z krytyki poznania uczynił punkt wyjścia dla filozofii, co pociagnęło $\mathrm{z}$ kolei determinację przedmiotu filozofii i wyznaczyło aprioryczne rozwiązanie kwestii związku danych świadomościowych z istnieniem realnego świata. Wspomniany tomista $\mathrm{z}$ danych czystej świadomości na podstawie zasady przyczynowości dochodził do egzystencjalnego sądu stwierdzającego istnienia świata. Rozwiązanie to jednak należy uznać za chybione ze względu na uprzednią w stosunku do rozumowania, założoną implicite prawdziwość tego sądu.

Dotychczasowe analizy postawiły w ostrzu krytyki nowożytne usytuowanie teorii poznania wśród dyscyplin filozoficznych. Teoria poznania jako filozofia pierwsza nie zajmuje się poznaniem, bo się nim zajmować nie może. Przecież pojęcie poznania jest wtórne wobec aktu istnienia czegoś. Nie istnieje poznanie bezprzedmiotowe. Fakt poznania można wyjaśnić tylko $\mathrm{w}$ powiązaniu $\mathrm{z}$ realnie istniejącym przedmiotem. Jeśli więc teoria poznania bada poznanie w oderwaniu od takiego przedmiotu, to tym samym redukuje poznanie do myślenia, nie pokazując przy tym żadnej drogi, na której myślący podmiot mógłby się wydostać z ,pułapki refleksji” i przejść do realnego świata.

\section{METODOLOGICZNY STATUS TEORII POZNANIA W TOMIZMIE} EGZYSTENCJALNYM

Odmienne rozwiązanie kwestii metodologicznego statusu teorii poznania prezentują tomiści egzystencjalni. Wspomniany kierunek filozofii jest dziełem francuskich filozofów Etienne Gilsona i Jacques'a Maritaina, a na terenie Polski Mieczysława A. Krąpca. Tomiści egzystencjalni zgodnie postulują, aby badania filozoficzne liczyły się z zastanym porządkiem rzeczywistości. Są przekonani, że filozofia, biorąc rozbrat z rzeczywistością, sztucznie generuje problemy filozoficzne. W taki też sposób narosło wiele problemów wokół kwestii wartościowego poznania. Problemy te ustapią, jeśli poznanie będzie wyjaśniane $\mathrm{w}$ związku $\mathrm{z}$ rzeczywistością. Wówczas teoria poznania o charakterze metaprzedmiotowym będzie zbyteczna, gdyż ta została utworzona na użytek

\footnotetext{
${ }^{22}$ Husserl utrzymywał, że ejdetycznym ujęciu poznawczym dochodzi do zderzenia subiektywności i transcendencji, przez co dociera się do samej istniejącej rzeczy.

${ }^{23}$ Zob. R. Ingarden, Spór o istnienie świata, t. 1-2, PWN, Warszawa 1960-1961.

${ }^{24}$ Zob. S. Adamczyk, Krytyka ludzkiego poznania, Towarzystwo Naukowe KUL, Lublin 1962.

${ }^{25}$ Por. A. Maryniarczyk, Tomizm, [w:] Powszechna encyklopedia filozofii, s. 507.
} 
rozwiązywania wspomnianych problemów. Nie znaczy to, że teoria poznania jako taka jest niepotrzebna.

W tomizmie egzystencjalnym utrzymuje się przekonanie, że teoria poznania wtedy uzyskuje swoją najgłębszą rację, jeśli wyjaśnia faktyczność poznania. Wyjaśnienie polega na ustaleniu tego, co jest faktem poznawczym, a następnie na wskazaniu takich czynników realnych, których ewentualna negacja byłaby negacją faktu ludzkiego poznania. Stosując metodę uniesprzeczniającego wyjaśnienia w odniesieniu do faktu poznania ustalamy te czynniki, które rozstrzygają o realizmie ludzkiego poznania i jego wartości. Jak widać, teoria poznania przejmuje od metafizyki realistycznej sposób postępowania wyjaśniającego. Cel wyjaśnień teoriopoznawczych jest analogiczny do celu, jaki stawia sobie metafizyka w odniesieniu do swojego przedmiotu formalnometodologicznego. Gdy dla metafizyki realistycznej jest nim wskazanie na ostateczne racje istnienia bytu jako bytu, tak dla teorii poznania celem tym jest wskazanie ostatecznych racji istnienia poznania.

Punktem wyjścia teorii poznania nie może być wtedy krytyka poznania, jak działo się to $\mathrm{w}$ jej koncepcji metaprzedmiotowej. „W procesie filozoficznego ukrytycznienia ludzkiego poznawania i wyjaśniania świata nastąpiło swoiste pomieszanie przedmiotu spontanicznego poznania ze sposobem samego poznania"26. Uprzedzającym wobec jakiejkolwiek krytyki poznania jest fakt poznania i ten - zdaniem Krapca - powinien stanowić właściwy przedmiot teorii poznania. Poznanie jest w tej dyscyplinie przedmiotem materialnym, formalno-treściowym - natomiast poznanie w aspekcie jego prawdziwości, formalno-metodologicznym zaś - poznanie prawdziwościowe pod kątem jego przyporządkowania do ostatecznych racji jego istnienia. Przedmiot teorii poznania to spartykularyzowany byt, czyli coś, co realnie istnieje. Poznanie jest zastanym, niesamozrozumiałym faktem, faktem do filozoficznego wyjaśnienia.

W punkcie wyjścia teorii poznania musimy przyjąć jakieś źródłowe pojęcie poznania. Faktyczności poznania nie wykazujemy, każdy bowiem je doświadcza, na jego podstawie organizuje sobie codzienne życie. Pojęcie poznania nie ma nad sobą rodzaju wyższego. Z tej racji jest pojęciem powszechnym i wymyka się definiowaniu. Nie można go zdefiniować bez popełnienia logicznego błędu circulus in definiendo. Analiza poznania dokonuje się właśnie w obrębie procesu poznania, a zatem jest już poznaniem. Źródłowo poznanie można jedynie opisać jako kontakt władz poznawczych z tym, co realnie istnieje. Ów kontakt zapoczątkowuje proces interioryzacji treści bytu przez poznającego z racji istnienia bytu ${ }^{27}$. Nie ma więc poznania bezprzedmiotowego, ale też nie ma poznania, o ile ten przedmiot realnie nie istnieje. Kontakt władz poznawczych z przedmiotem intencjonalnym nie jest poznaniem, lecz myśleniem, refleksją. Zdaniem tomistów egzystencjalnych błąd filozofów świadomości polega na redukowaniu poznania do badania zawartości strumienia ludzkiej świadomości. Tymczasem w rzeczonej analizie wyczerpuje się tylko ludzkie myślenie. Inaczej jest z poznaniem, które jest konieczna relacją podmiotu do takiego przedmiotu, który faktycznie istnieje.

Poznanie ma nie tylko swe racje w poznającym podmiocie. Akt poznania powstaje w relacji poznającego podmiotu do faktycznego istnienia. Podmiot ze względu na istnienie poznaje. I chociaż istnienie jest racją poznania, to jest ono poznawalne $\mathrm{w}$ relacji do

\footnotetext{
${ }^{26}$ M. A. Krapiec, O filozofii, s. 77.

${ }^{27}$ Por. idem, Poznanie istniejacych rzeczy, [w:] Powszechna encyklopedia filozofii, red. A. Maryniarczyk i in., t. 8, Polskie Towarzystwo Tomasza z Akwinu, Lublin 2007, s. 396.
} 
bytowej treści. Z tego wynika, że struktura realnie istniejącego bytu rozstrzyga o strukturze aktów poznawczych ${ }^{28}$. Ujęcie poznawcze bytu nie może być adekwatne w poznaniu czysto pojęciowym. Poznanie pojęciowe dotyczy tylko treści rzeczy materialnej. Natomiast poznanie prawdziwościowe odbywa się wówczas, gdy treść bytu jest ujmowana $\mathrm{w}$ przyporządkowaniu do faktycznego jej istnienia, a wtedy poznanie ma charakter sądowy i polega na intelektualnym „wyjmowaniu” ze świata rzeczy poszczególnych relacji połączonych naturalnym układem korelatów bytowych.

Chociaż tomiści egzystencjalni uważają poznanie za właściwy przedmiot teorii poznania, to przecież istnieje wiele typów poznania. Nasuwa się pytanie, czy przedmiotem teorii poznania jest poznanie w ogóle, czy też jakiś jeden wybrany typ poznania. Krapiec uważa, że do poznania dochodzimy źródłowo, badając typ poznania zdroworozsądkowego. W nim rozeznajemy otaczający nas świat, organizujemy sobie warunki codziennego życia ${ }^{29}$. I ono także dostarcza materiału dla uzasadnienia faktu poznania istnienia bytu, a także istniejących realnych treści bytowych ${ }^{30}$. Poznanie zdroworozsądkowe, będąc podstawowym i powszechnym typem poznania, jest później, w zależności od potrzeb i możliwości, rozwijane w innych typach poznania. Jako poznanie spontaniczne angażuje wszystkie władze poznawcze podmiotu w ujmowanie zarówno faktu istnienia rzeczy, jak i jego struktury, poprzez spontanicznie tworzone pojęcia i sądy, w momencie poznawczego dostrzeżenia jakieś rzeczy.

Status metodologiczny teorii poznania w tomizmie egzystencjalnym dookreśla jej stosunek do metafizyki. W programie tomizmu egzystencjalnego wskazywano metafizykę realistyczną jako filozofię pierwszą. $Z$ tej racji jest ona centralną dyscypliną filozoficzną. $\mathrm{Z}$ nią strukturalnie związane są tak zwane metafizyki szczegółowe, które wyznaczają dziedziny filozoficznych badań. Metafizyka za swój punkt wyjścia obiera egzystencjalnie rozumiany byt. W nim akt istnienia jest najważniejszym i najdoskonalszym czynnikiem bytowym. Byt $\mathrm{w}$ aspekcie istnienia jest przedmiotem formalnym filozofii realistycznej. Krapiec uczynił z pojmowanego w ten sposób przedmiotu zasadę łączącą wszystkie działy filozofii wyjaśniającej poszczególne obszary rzeczywistości. W filozoficznym programie tomizmu egzystencjalnego teoria poznania ma status metafizyki szczegółowej ${ }^{31}$. W przeciwieństwie do metafizyki, której przedmiotem jest byt jako byt, teoria poznania ma za swój przedmiot jedną z kategorii bytu, a mianowicie fakt poznania. $\mathrm{Z}$ racji badania przez nią realnie istniejącego przedmiotu słusznie nazywa się ją teorią poznania o charakterze przedmiotowym. A będąc dyscypliną przyporządkowaną i podporządkowaną metafizyce, określa się ją również jako metafizykę poznania.

\section{LITERATURA}

[1] Adamczyk S., Krytyka ludzkiego poznania, Towarzystwo Naukowe KUL, Lublin 1962.

[2] Chudy W., Rozwój filozofowania a „,pułapka refleksji”, Redakcja Wydawnictw KUL, Lublin 1995.

\footnotetext{
${ }^{28}$ Por. ibidem.

${ }^{29}$ Por. idem, Epistemologia, s. 193, 200.

${ }^{30}$ Por. ibidem, s. 200.

${ }^{31}$ Por. A. Maryniarczyk, Przełom w dziejach polskiej filozofii, „Człowiek w Kulturze” 2007/19, s. 87-88.
} 
[3] Descartes R., Medytacje o filozofii pierwszej, przeł. J. Hartman, Zielona Sowa, Kraków 2006.

[4] Descartes R., Rozprawa o metodzie, przeł. T. Żeleński-Boy, Wydawnictwo Marek Derewecki, Kęty 2009.

[5] Filozofia, podstawowe pytania, red. E. Martens i H. Schnadelbach, przeł. K. Krzemieniowa, Wiedza Powszechna, Warszawa 1995.

[6] Ingarden R., Spór o istnienie świata, t. 1-2, PWN, Warszawa 1960-1961.

[7] Kalinowski J., O istocie i jedności filozofii, „Roczniki Filozoficzne” 6/1 (1958), s. 5-17.

[8] Kamiński S., Dziedziny teorii bytu, [w:] Studia z filozofii Boga, red. B. Bejze, t. 3, Warszawa 1977, s. 78-100.

[9] Kamiński S., Teoria bytu a inne dyscypliny filozoficzne, „Roczniki Filozoficzne" 25/1 (1975), s. 5-18.

[10] Kant I., Krytyka czystego rozumu, przeł. R. Ingarden, t. 1-2, PWN, Warszawa 1986.

[11] Krapiec M.A., Epistemologia, [w:] Powszechna encyklopedia filozofii, red. A. Maryniarczyk i in., t. 3, Polskie Towarzystwo Tomasza z Akwinu, Lublin 2002, s. 193-200.

[12] Krapiec M.A., O filozofii, Polskie Towarzystwo Tomasza z Akwinu, Lublin 2008.

[13] Krapiec M.A., Poznanie istniejacych rzeczy, [w:] Powszechna encyklopedia filozofii, red. A. Maryniarczyk i in., t. 8, Polskie Towarzystwo Tomasza z Akwinu, Lublin 2007, s. 396-404.

[14] Mansion A., Philosophie première, philosophie seconde et métaphysique chez Aristote, ,Revue Philosophique de Louvain” 1958/56, s. 165-221.

[15] Maryniarczyk A., Przełom w dziejach polskiej filozofii, „Człowiek w Kulturze" 2007/19, s. 73-97.

[16] Maryniarczyk A., Tomizm, [w:] Powszechna encyklopedia filozofii, red. A. Maryniarczyk i in., t. 9, Polskie Towarzystwo Tomasza z Akwinu, Lublin 2008, s. 503-508.

[17] Paź B., Naczelna zasada racjonalizmu, Aureus, Kraków 2007.

[18] Reinhold E., Theorie des Menslichen Erkenntnisvermögens und Metaphysik, I-II, Gotha 1832-1835.

[19] Stępień A.B., Wstęp do filozofii, Towarzystwo Naukowe KUL, Lublin 2007.

[20] Suárez F., Disputationes metaphysicae, Bd. 2, Hildesheim 1998.

[21] Szulakiewicz M., Transcendentalizm Kanta a myśl współczesna, [w:] Immanuel Kant i świat współczesny, red. K. Śnieżyński, Uniwersytet im. Adama Mickiewicza, Poznań 2004.

[22] Św. Tomasz z Akwinu, Summa contra gentiles, t. 2, Casa Editrice Marietti, Roma-Torino 1946.

[23] Wciórka L., Teoria poznania, Papieski Wydział Teologiczny Redakcja Wydawnictw, Poznań 1996.

[24] Woleński J., Epistemologia, Wydawnictwo Naukowe PWN, Warszawa 2005. 


\section{DISCUSSIONS ABOUT THE METHODOLOGICAL STATUS OF THE THEORY OF KNOWLEDGE IN THE PHILOSOPHY OF THE SUBJECT}

In this article the author examines the question of the status of the methodological theory of knowledge in the mainstream of classical philosophy and in modern the philosophy of the subject. Over the centuries, the status methodological of the theory of knowledge evolves. Theory of knowledge is becoming increasingly important. In the end ranks first among the philosophical disciplines, this takes place in the modern philosophy of the subject. He points to the difficulties associated with the perception of epistemology as first philosophy. The author shows the way in which the theory of knowledge has become the philosophy of the first and the negative consequences of this status of epistemology for practicing the philosophy. The most important among the many negative consequences of is that philosophy has lost its relationship with the real world. In this way, she closed her knowledge in box of human consciousness. In result knowledge has been replaced by reflection on our own cognitive acts. Thinking human subject has lost the ability to control their cognitive processes by recourse to of real being. According to the Thomistic existential negative consequences can be removed by changing the status of methodological theory of knowledge. The starting point the theory of knowledge is to describe fact of knowledge. The aim of the theory of knowledge is a philosophical explanation of this fact. Then the theory of knowledge is metaphysics detailed.

Keywords: philosophy of subject, classical philosophy, the philosophy of the first, the theory of knowledge, metaphysics, Thomism existential.

DOI:10.7862/rz.2013.hss.22

Tekst złożono w redakcji: maj 2013

Przyjęto do druku: wrzesień 2013 